\title{
The Bronze Coins of Alexander the Great in NEMC Collection
}

Dalia Amine*, Nagoua Zoair, Wahid Omran

Faculty of Tourism and Hotels, Fayoum University, Egypt:

\section{ARTICLE INFO}

Keywords:

Monetary

Alexander

Egypt

Aphlaston.

\begin{abstract}
The National Museum of Egyptian Civilization (NEMC) has preserved since 2007 a collection of coins that were donated by Emma Jacot to the Greco-Roman Museum of Alexandria in 1953. The coins represented with the figure of Alexander the Great as a young man with a different hairstyle on the obverse and the Ptolemaic eagle on the reverse; are three examples of this type there are carried with the index numbers (26280, 2628, and 26279), denoting the influence of this leader on the early denomination of bronze coins of Ptolemaic Period. This research aims to study the character of the early Ptolemaic monitoring system and the significance of the depiction of Alexander the Great with the available examples. The results highlighted the Ptolemaic policy of taking advantage of Alexander to reinforce the Ptolemaic kingdom in Egypt.
\end{abstract}

C2021 Faculty of Tourism and Hotels, Fayoum University All rights reserved

\section{Introduction}

The collection of NEMC which includes bronze and silver coins includes a great number that covers chronologically all the Ptolemaic Period. It represents a complete image of the monetary system of denomination and iconography. Also, the collection gives a clear image of the economic, social, political, and religious aspects of that period.

In his different attempts to reinforce his new kingdom, Ptolemy I implemented a monetary system that lasted until the end of the Ptolemaic dynasty. He introduced multiple coins where he many gods represented and goddesses as Alexander the Great wearing the elephant scalp, the seated Zeus on the throne holding the religious symbols, the head of Herakles wearing lion's glade, the ram's horns, and the royal Aegis, and Isis.

\footnotetext{
* Contact Dalia Amine at: dalia.amine@gmail.com
}

Precious metals as gold and silver were firstly used to form the coinage system. Alongside, small bronze and copper were also raw materials that formed a variety of coins in Alexandria. The first denomination represents the feature of Phoenician style the so-called Attic standard with the silver Tetradrachm that weighted $17.80 \mathrm{gr}$; it continued for a while in Egypt but later was decreased to be around 14.25 and the so-called the Ptolemaic standard started to be more legalized.

The coins were not only used for economic purpose, but it was a means of political propaganda, indicators of welfare, and religious affiliation. Therefore, the study of the monetary system reveals insights about the economic, social, religious, and political state in any period that belongs. 


\section{Literature review}

\subsection{Bronze coins}

The evidence of the Ptolemaic bronze coins during the early three years of his reign as satrap is very rare in Egypt. The reason is unknown, but this may be due to the different classes of the population such as the peasantry, artisans, and craftsmen who were not familiar to use the coins, originally the idea of the coinage was not popular among different categories of people (Milne, 1938, p. 202).

Milne (1938, p.2003) mentioned that the small denomination of the bronze coins was minted in the early time of the Ptolemy royal era as a commemorative portion and later it was used for covering the internal needs. Unlike the gold and silver coins, bronze coins were modelled to use mainly for economic purposes: daily life activities, collecting taxes, soldiers' payoff, and employees' salaries. Despite that, it was decorated with the same monograms and religious symbols of other types of coins.

During the Ptolemaic Period, the manufacturing of bronze coins was subject to some reforms. The first reform was made by king Ptolemy II Philadelphus (285- 246 B.C). This type of coins was reformed after 266 B.C and expanded to include an array of unprecedented large denominations, in different categories. The most important of these, was the types of $42 \mathrm{~mm}$ diameter and 72 grams in weight, with two eagles on the reverse standing on a thunderbolt; the so-called Drachm appeared with the presence of central cavities, and these were struck in both of Syria and Phoenicia. It was so remarkable that Ptolemy II increased the sizes of all denominations, but he kept the small pieces of the $14 \mathrm{~mm}(1 / 2 \mathrm{Obol})$ and $21 \mathrm{~mm}(\mathrm{Obol})$ for the daily needs (Sitta, 2015, p. 63-64). Both silver and bronze were legal tenders to any amount in Egypt. There is no adjustment between the two different materials for the reckoning of the payments, the diffuse of the bronze coins drove out the silver coins from the currency circulation, and the trade of Egypt called for a large supply of the coins with high value. The people obtained the coins with their heavyweight as bigger face value. Comparing the coin weight with Ptolemy I Soter, it became six times of the largest or the chief bronze coins, and it was taken as drachmas and as result, the amount of the silver coins in the hordes expedition became much less compared with the bronze of the middle of the third century B.C. (Minle, 1938, p. 203-207). The second reform occurred during the reign of Ptolemy III, in 241 B.C. and it was arranged as the $4^{\text {th }}$ series of coins (Lorber, 2018, p. 82).

\subsection{Alexander coins}

After Alexander's death, Ptolemy continued to make the same issue of Alexander coins with the name and the image of Alexander to show his loyalty to his leader. The first example in Alexandria was figured with the legend of Alexander $\mathrm{A} \Lambda \mathrm{E} \Xi \mathrm{AN} \Delta \mathrm{P}$ wearing the elephant scalp; it was made of bullion with Ptolemaic standard (Robert, 1998, p.3-4.). On the reverse, the Ptolemaic eagle was figured as a remarkable sign of Ptolemaic royalty and it is represented, therefore, on a vast majority of their coins, the double eagle comes in the second rank of the popularity of the reverse type (Faucher and Larbor, 2010, p. 36).

After a few years, the obverse of the coin was modified; it was figured with Herakles' head and Alexander's with an elephant scalp, referring to Alexander's victories in India. The reverse was altered as the striking appearance of fighting Athena Alkidome instead of the figure of seated Zeus, but the legend of Alexander was still used (Thompson, 1982, p. 14). It can be dated to 318315 B.C. in Alexandria, due to the inscription "A $\lambda \varepsilon \zeta \alpha v \delta \rho \varepsilon เ \gamma^{\prime}$ " which means Alexander - coins with its typical Attic standard with $17.5 \mathrm{~g}$.

\subsection{The coins of Alexander the Great in the NEMC collection}

\subsubsection{First coin}

Index number: 26280

Material: $\quad$ Bronze Hemiobol

Weight: $\quad 10 \mathrm{gr}$

Diameter: $\quad 8 \mathrm{~mm}$

Approximate date: 310-305 (Ptolemy I - Soter)

Compared Sv. 156 


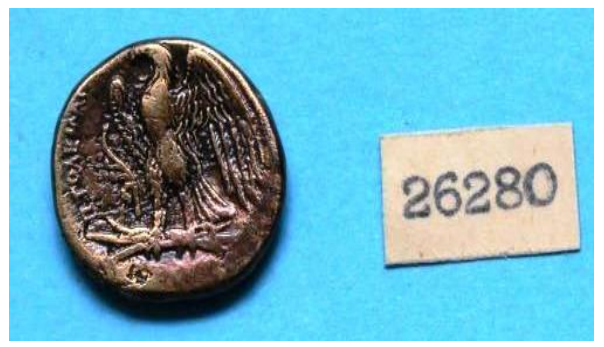

$\boldsymbol{O} \boldsymbol{b}$ / diademed head of Alexander the great with long hair, surrounded by tatina, including the horn of Zeus Ammon, flat border.

$\boldsymbol{R e v} /$ Eagle standing on a thunderbolt, open spread wings, the Aphlaston is on the left field, the remains of the legend still exist ПТО $\Lambda$ EM.., flat border.

\section{Description}

The obverse has a presentation of the bust of Alexander the great as a young man with long hair diademed with tatina, the horn of Zeus Ammon is above the forehead, the hairstyle is well organized the hair braids hang down from the back head central point, downward the face direction, the royal tatina is well tied behind the neck, the hair braids comes in four wavy long lines. Reaching to the shoulder, the ear is a middle size followed with sideburn, the face has serious features without reactions, the forehead is ting, the eye is oblong, stretched style which is different from the

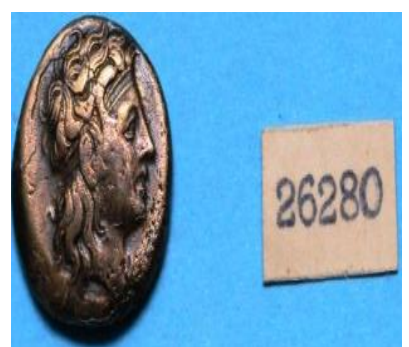

Ptolemaic rounded eyes, the nose is straight and pointed, the mouth is small with closed lips, the cheekbones and the chin is full, the neck is long and bulging, the head is in the coin center, and the border is flat.

The reverse shows an eagle standing on a thunderbolt, with open spread right-wing reaching to the coin edge, the eagle feathers are arranged in straight lines very obvious in the right wing and tail, the eagle legs are dotted, the eagle hooves are well catching their thunderbolt is an Aphlaston to the left-field, the first part of the legend is $\Pi \mathbf{T O} \mathbf{\Lambda E}$ $\ldots$, there is no space second part $-\mathrm{BA} \Sigma \mathrm{E} \Lambda \Omega \Sigma$.

\subsubsection{Second coin}
Index
Number: 26281
Material
Bronze Hemiobol
Weight
$8 \mathrm{gr}$
Diameter
$16 \mathrm{~mm}$
Approximate date 310-304.

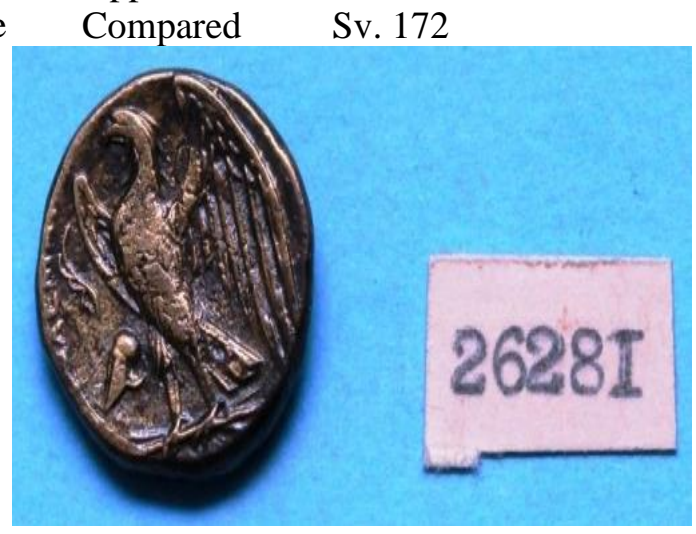

the lower coin part, the hair is long and flying up, the eye is looking up, the face is much smaller, the border is flat. The reverse shows a small eagle standing on the left field under the aphlaston.

\subsubsection{Third coin}

Index number 26279

Material Bronze Hemiobol

Weight $8 \mathrm{gr}$

diameter $\quad 15 \mathrm{~mm}$

Mint Cyprus or Alexandria 
Approximate 310-304

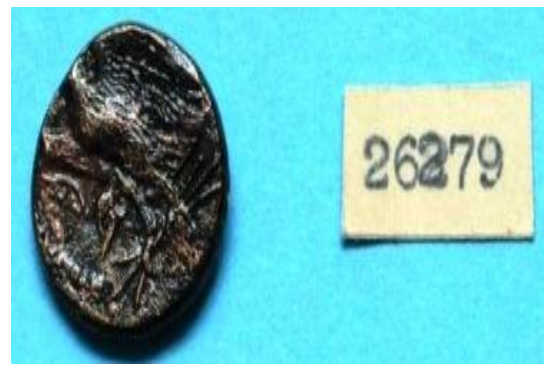

Compared Sv. 172; Catharine, L., Development of Ptolemaic-Bronze Coinage in Egypt, 2010, P1. I. coin. no 3.

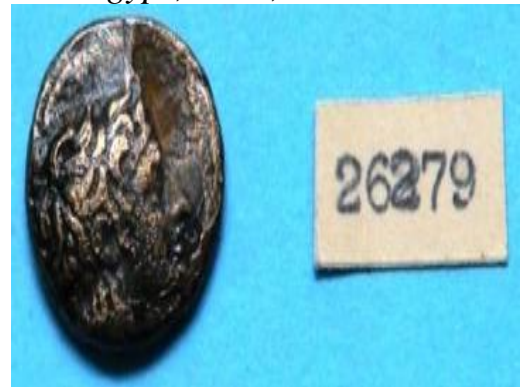

$\boldsymbol{O b} /$ diademed head of Alexander the great with long hair, the tatena is surrounding the head, the horn of Zeus- Ammon represented here in a small size.

Rev/ Eagle standing on a thunderbolt, open wings and the head is damaged, the remains of a small eagle and Aphlaston is not clear on the left-field. 3.1. The Bronze Coinage (320 - 315) B.C.

According to the study of Abdel Aziz (2013), the earliest Ptolemy's bronze coinage appeared during the Satrapal time 320/19 to 314 B.C, the obverse bears the deified Alexander with curly short hair and the horn of Ammon, the "Mitra" (the tied strip around the head) of Dionysus tied around the forehead, the reverse showed an eagle standing and perching on a thunderbolt; the larger diameter of $18-20 \mathrm{~mm}$ was $4 \mathrm{gr}$ of weight. and the legend was $\mathrm{A} \Lambda \mathrm{E} \Xi \mathrm{AN} \Delta \mathrm{P} \quad$ (Alexander), the smaller denomination was $10 \mathrm{~mm}$ diameter and 1. gr in weight, the letters $\mathrm{A} \Lambda \mathrm{E}$ was recorded on the leftfield to indicate that the coins were issued to honor Alexander the great with his name. Most of the bronze denominations were struck in order to make a balance with the other precious metals, later in 315 B.C. the Alexander bronze coinage with the previous configuration was terminated except the introduction of the Alexander type of the Athena Alkis reverse, which was between 1 to 2 gr. qualified as Chalqous (Noeske, (2000, nos 10 and 11)

3.2 Ptolemy I bronze coins with Alexander shorthaired type 312 till being a king

According to Davesne (1998, 49-50), three denominations were minted at this period, with a diademed head of Alexander with long hair on the obverse and standing eagle on the reverse with a small eagle on the left field and that was during the first occupation time of Cyprus by Ptolemy in 312$310 \mathrm{BC}$, he mentioned also that the three denominations varied in weight from 1,4 to 9 gr. (Larbor, 2007, p. 135) the Ptolemaic Attic divisional system was each eight Chalquoi versus $1 \mathrm{Obol}$ and these pieces of the $4 \mathrm{gr}$ were much popular in use, so the three denominations of Ptolemy satrap were Chalqous, Himobl, and Obol. In 304 B.C the Alexander coinage with long hair was redesigned representing Alexander with long hair with the horn of Ammon and the "mitre" of Dionysus tied around the head (Larbor, 2007, 136). The historical condition of this period was very complicated because of military actions that were going on among the successors of Alexander the great, so most of the scholars have dated the bronze coins according to their weight. Lorber Divides the later denomination of Ptolemy I after the satarpal period into three series according to the control mark and the weight:-

1- The first series feature with the helmet symbol in the coin field with the Legend $\beta A \Sigma \mathrm{I} \Lambda \mathrm{E} \Omega \mathrm{E}$ ПTO $\mathrm{EMAIOY} \mathrm{(Ptolemy} \mathrm{the} \mathrm{king)} \mathrm{with}$ reduced - the weight of Alexander Tetradrachms in 312/310 - 305/4 B.C, this series was considered to be the first series of Ptolemy I bronze coins as a king.

2- The second bronze series was featured with Aphlaston and with Ptolemy name without the royal title, Just " ПTO $\Lambda$ EMOIY" for example "S.v172) and the eagle standing on the reverse with the Aphlaston and little eagle on the coin field, both of the helmet and the were military symbols during the early years of Ptolemy I as a king.

3- The third series was also struck with Ptolemy's name only with no symbols, but with control marks of the gold Staters of the Ptolemy with his face portrait, and the elephant quadriga was represented on the reverse. the military symbols of the bronze coins were introduced 
parallel to the military mission in Cyprus and Syria before 302/301 BC

On the other hand, the other metals such the gold and silver became rare in Egypt because of the soldiers and mercenaries payment, so the bronze coins were minted to use for supplying them and was used also to be a good way for collecting the internal taxis

The series and the denominations were not the only methods used to estimate the coins categories, the weight of the bronze coins was also important to figure out the coins' date and value, Lorber depends on the previous study of Davesne in 1998, that considered the 1 gr. as Chalqous but his largest weight was 37. gr represented the triobols, that were not included in Larbor study and that could be followed on Larbor comparison as Triobol was 24 gr with $32 \mathrm{~mm}$, while the Davense largest one was $37 \mathrm{gr}$ as Tetrobol. So the similar categories for both themes were the one Chalqous of $1 \mathrm{gr}$.

Actually, our consideration is not the large denomination, because it is not available in our collection.

\section{Conclusion}

The three examples of the coins that we have in the inventory of this study belong to the second series of Catharine Lorber's division the best one of them is number. 26280 (pl.no.5) with 9 gr. and $15 \mathrm{~mm}$, the same one of Catharine collection and (Sv. 156) it has on the obverse a representation of Alexander the great with long flowing hair with very obvious face details, on it is reverse there is an eagle standing on a thunderbolt with the Aphlastion and the legend of ПTO $\triangle \mathrm{EMOIY,} \mathrm{without} \mathrm{the} \mathrm{royal}$ title, she dates this series to the beginning of Ptolemy Soter's royal reign 305/4 B.C. it means that he replaced the inscription $\beta \alpha \Sigma i \lambda \varepsilon \Omega \Sigma$ A $\lambda \varepsilon \zeta \alpha v \delta \rho \circ$ with $\Pi \tau$ o $\lambda \varepsilon \mu \alpha$ ioy, but he kept Alexander's portrait. Milne mentions that this small denomination of the bronze coins were minted in the early time of Ptolemy royal era as a commemorative portion and later it was used for covering the internal needs such the internal trade, military supplements, and taxes payments.

The second example that we have in our catalogue is number $26281(\mathrm{Pl}-$ no. 2) is also a Himobl with 8. gr. $16 \mathrm{~mm}$, the only difference is the representation of the (little Eagle under the Aphlastion on the left field in front of the big standing eagle, Svoronos referred to its date to $310 / 4$, that was before taking the royal title and also before losing Cyprus to the Antogied family in 306 B.C. Maybe he was considered the little eagle as a symbol of the victory and summation of Alexander the Great as a descendant of god Zeus with the same traditions.

The third example that exists in this study is coin number 26279 which resembles the previous one, but unfortunately, its condition is very bad, so the details are hard to be figured.

But the coin size is very small so maybe it was struck as a commemorative portion in order to honor Alexander the great as Milne suggests So from the previous information, we can identify the three bronze coins in our catalogue with the second series of Ptolemy I bronze portions and those can be dated it to 310/304 B.C depending on their weight and their control marks.

\section{References}

Bouyon, B., et al. (2000), Système et Technologie des Monnaie de Bronze (IVe avant J.C.- III 's après J.C.), Wetteren.

Davesne, A. (1998). Réflexions Sur la Valeur des Bronzes des Premiers Ptolémée. Revnam

Faucher, Th, and Larbor, C. (2010). Bronze Coinage of Ptolemaic Egypt in The Second Centyry B.C. AJN, 22, 35-80.

Larbor, C., (2018). Coins of The Ptolemaic Empire, Ptolemy I Through Ptolemy IV, part. 1, New York.

Larbor, C., (2007). The Ptolemaic Era Coinage Revisited. The Numismatic Chronicle, 167, 105118.

Manning, J. G., (2006). Coinage as 'Code' in Ptolemaic Egypt, SSRN, 2006, 1, 1-41.

Milne, J. G. (1938). The Currency of Egypt under the Ptolemies. Journal of Egyptian Archaeology, 24, 1938, .200-207.

Mörkholm, O. (1976). The Ptolemaic Coins of An Uncertain Era, Stockholm.

Noeske, H.-C. (2000). Die Münzen der Ptolemäer: die Bestände des Münzkabinetts. Historisches Museum frankufurt am main, Frankfurt.

Pincock, R. (2012). Are there Denominational Indicators on Ptolemaic Bronze Coins? The numismatic chronicle, 172, 35-46.

Robert, K. R., (1998). Egypt under the Ptolemies: The Legacy of Ancient Egypt, in The Cambridge History of Egypt, 1, 3-13.

Sitta, V, R., Money in Ptolemaic Egypt from the Macedonion Conquest to The End of The Third Century B.C, Cambridge, 2015.

Thompson, M., "The Coinage of Philip the II and Alexander III", ANC, Maccedonia and Greece in late classica land early Hellenistic times, Washington, 1982, pp. 113-121 